\title{
EDUCORETAX
}

Volume 1 No. 2, Juni 2021

\section{PENERAPAN INSENTIF PAJAK PENGHASILAN FINAL BAGI UMKM DI KPP PRATAMA BALIGE PADA MASA PANDEMI COVID-19}

\author{
Rani Santhy L Sitindaon ${ }^{1)}$; Agus Bandiyono ${ }^{2)}$ \\ 1) ranisitindaon@gmail.com, Politeknik Keuangan Negara STAN \\ 2) agusbandiyono@pknstan.ac.id, Politeknik Keuangan Negara STAN
}

\begin{abstract}
This study aims to conduct a review of the implementation of PMK 86/PMK.03/2020 on tax incentives for MSMEs at KPP Pratama Balige, to conduct a review of its effectiveness, and to identify obstacles that occur in the implementation. The research method used to obtain and analyze data is documentation method and interview method. Based on the review of the implementation PMK 86/PMK.03/2020 on tax incentives for MSMEs at KPP Pratama Balige, it can be concluded that : implementation of PMK 86/PMK.03/2020 on tax incentives for MSMEs at KPP Pratama Balige has been implemented in accordance with the regulation, but there are still a few MSMEs who use these incentives; Reviewing the effectiveness of PMK 86/PMK.03/2020 on tax incentives for MSMEs at KPP Pratama Balige, it can be concluded that the use of PMK 86/PMK.03/2020 on tax incentives for MSMEs at KPP Pratama Balige needs improvement. The enactment of PMK 86/PMK.03/2020 to provide incentives for MSMEs does not make a reduction in MSMEs Final Income Tax receipts even though it is known that by using these incentives, taxpayers no longer need to make tax payments; The identification of obstacles in the implementation of PMK 86/PMK.03/2020 on tax incentives for MSMEs at KPP Pratama Balige, the authors conclude that there are obstacles, both from the revenuer and from MSMEs Taxpayer.
\end{abstract}

Keywords : Tax administration; public administration; tax incentives; taxation; taxpayer

\begin{abstract}
Abstrak
Penelitian ini bertujuan untuk melakukan tinjauan atas implementasi PMK No 86/PMK.03/2020 atas insentif pajak bagi UMKM di KPP Pratama Balige, tinjauan efektivitasnya, dan mengidentifikasi hambatan atas implementasi tersebut. Metode penelitian yang digunakan untuk memperoleh dan menganalisis data adalah metode dokumentasi dan metode wawancara. Berdasarkan tinjauan implementasi PMK No 86/PMK.03/2020 atas insentif pajak bagi UMKM di KPP Pratama Balige, maka dapat ditarik kesimpulan bahwa : implementasi PMK No 86/PMK.03/2020 atas insentif pajak bagi UMKM di KPP Pratama Balige telah diterapkan sesuai dengan aturan yang berlaku, namun masih sedikit Wajib Pajak UMKM yang memanfaatkan insentif tersebut; Pada tinjauan efektivitas pemanfaatan PMK No 86/PMK.03/2020 atas insentif pajak bagi UMKM di KPP Pratama Balige, maka dapat disimpulkan bahwa pemanfaatan PMK No 86/PMK.03/2020 atas insentif pajak bagi UMKM di KPP Pratama Balige masih membutuhkan penyempurnaan. Hal ini dikarenakan berlakunya PMK No 86/PMK.03/2020 untuk memberikan insentif bagi UMKM, tidak serta merta menyebabkan berkurangnya penerimaan PPh Final UMKM meskipun diketahui bahwa dengan memanfaatkan insentif tersebut Wajib Pajak tidak perlu lagi melakukan penyetoran pajak; Dari identifikasi hambatan dalam implementasi PMK No 86/PMK.03/2020 atas insentif pajak bagi UMKM di KPP Pratama Balige, penulis menyimpulkan masih terdapat hambatan, baik dari sisi fiskus maupun dari sisi Wajib Pajak UMKM.
\end{abstract}

Kata Kunci : Administrasi perpajakan; administrasi publik; insentif pajak; perpajakan; Wajib Pajak

\section{PENDAHULUAN}

Organisasi Kesehatan Dunia atau World Health Organization (WHO) menetapkan Corona Virus Disease 2019 (COVID-19) sebagai pandemi global pada Maret 2020. Protokol Percepatan Penanganan Pandemi COVID-19 (2020) menyatakan bahwa sebaran 118.000 kasus yang menjangkiti 114 negara di dunia menjadi dasar ditetapkannya pandemi tersebut. Penyebaran COVID-19 sebagai pandemi di negara-negara dunia, mengalami peningkatan terus menerus dan banyak menimbulkan korban jiwa serta kerugian yang kian besar (Permadhi \& Sudirga, 2020). Peningkatan penyebaran COVID-19 tersebut berimplikasi pada berbagai aspek, antara lain, aspek sosial, aspek ekonomi dan kesejahteraan masyarakat (Iswanto \& Surisman, 2020). Sebagai negara yang terdampak, implikasi pandemi COVID-19 di Indonesia telah berpengaruh terhadap kestabilan perekonomian dan keproduktifan masyarakat sebagai karyawan maupun pemilik usaha. Sebagai langkah untuk mengurangi dampak tersebut, maka pemerintah perlu melakukan penyelamatan perekonomian nasional dengan fokus pada strategi pemulihan perekonomian para pemilik usaha dan rakyat terkena imbasnya (Marlinah, 2020). 


\section{EDUCORETAX}

Volume 1 No. 2, Juni 2021

Dunia usaha yang sangat terdampak dengan merebaknya pandemi COVID-19 ialah sektor Usaha Mikro Kecil dan Menengah (UMKM) (Thaha, 2020). Berdasarkan Undang-Undang No 20 Tahun 2008 Tentang Usaha Mikro, Kecil, dan Menengah, dijelaskan bahwa UMKM adalah bisnis aktif yang dimiliki oleh perseorangan atau badan usaha yang memenuhi standar tertentu yang telah ditetapkan. Laporan Analisis Daya Saing UMKM Di Indonesia (2014) oleh Badan Perencanaan Pembangunan Nasional (BAPPENAS), menyatakan bahwa UMKM di Indonesia memiliki beberapa peran yang cukup besar antara lain, memperluas kesempatan kerja dan menyerap tenaga kerja, membentuk produk domestik bruto (PDB) dan memberikan jaring pengaman, terutama bagi masyarakat berpenghasilan rendah. Hal itu dibuktikan dengan jumlah unit usaha, serta kontribusi UMKM terhadap serapan tenaga kerja dan pembentukan PDB. UMKM memiliki posisi penting dalam perekonomian nasional (Setyawati, 2009). Data Kementerian Koperasi dan Usaha Kecil dan Menengah Republik Indonesia menunjukkan perimbangan statistik UMKM tahun 2018. Sektor UMKM sebanyak 99,9\% dari jumlah sektor usaha atau 62,9 juta sektor usaha, 98,68\% diantaranya berasal dari sektor mikro. Selanjutnya untuk serapan tenaga kerja adalah $97 \%$ dari jumlah penyerapan tenaga kerja, dan menyokong 61,07\% terhadap PDB (Kementerian Koperasi dan UKM, 2018). Melihat peran UMKM sebagai penyokong perekonomian di Indonesia, menjadi sangat penting bagi pemerintah untuk tetap menjaga kelangsungan UMKM di masa pandemi COVID-19. Salah satu upaya Pemerintah untuk menjaga produktivitas sektor UMKM adalah memberikan insentif pajak.

Pemerintah melalui Kementerian Keuangan dan Direktorat Jenderal Pajak (DJP) menerbitkan Peraturan Menteri Keuangan (PMK) No 86/PMK.03/2020 Tentang Insentif Pajak Untuk Wajib Pajak Terdampak Wabah Virus Corona. Salah satu sasaran peraturan tersebut ialah memberikan insentif pajak bagi UMKM, yaitu Pajak Penghasilan final ditanggung pemerintah. Pasal 5 ayat 1 PMK No 86/PMK.03/2020 mengatur bahwa "atas penghasilan dari usaha yang diterima atau diperoleh Wajib Pajak yang memiliki peredaran bruto tertentu sesuai ketentuan sebagaimana dimaksud dalam Peraturan Pemerintah Nomor 23 Tahun 2018, dikenai PPh final sebesar 0,5\% (nol koma lima persen) dari jumlah peredaran bruto." Selanjutnya dalam Pasal 5 ayat 3 PMK No 86/PMK.03/2020 diatur bahwa "PPh final sebagaimana dimaksud pada ayat 1, ditanggung Pemerintah." Adapun maksud dari ditanggung pemerintah adalah atas penghasilan tersebut tidak dilakukan perhitungan menjadi penghasilan yang dikenakan pajak. Pemberian insentif tersebut berlangsung sejak bulan April sampai dengan bulan Desember 2020. Harapan pemerintah dengan diterbitkannya PMK No 86/PMK.03/2020, UMKM dapat memanfaatkan insentif tersebut dengan tujuan roda perekonomian tetap bergerak sehingga pertumbuhan ekonomi tetap stabil. Pemerintah, melalui Kementerian Keuangan mencatatkan hasil pemanfaatan insentif pajak berupa fasilitas $\mathrm{PPh}$ final UMKM ditanggung pemerintah hingga tanggal 3 September 2020, masih sebesar Rp 300 miliar atau 12,5\% dari anggaran sebesar Rp 2,4 triliun (Wildan, 2020). Pemanfaatan insentif tersebut tergolong rendah.

Penelitian terdahulu menunjukkan bahwa sosialisasi dan pemahaman PMK No 86/PMK.03/2020 berpengaruh positif terhadap kemauan menjalankan kewajiban perpajakan di masa pandemi COVID-19 (Mudiarti \& Mulyani, 2020). Terdapat kesenjangan antara penelitian terdahulu dan fakta yang terjadi di lapangan. Sebagai objek penelitian, penulis memilih Kantor Pelayanan Pajak (KPP) Pratama Balige. Pemilihan tersebut didasarkan atas adanya informasi yang diperoleh dari hasil wawancara dengan seorang Account Representative di KPP Pratama Balige, yang menyatakan bahwa sesudah diterbitkannya PMK No 86/PMK.03/2020, KPP Pratama Balige telah melakukan sosialisasi PMK No 86/PMK.03/2020 kepada UMKM yang terdaftar di KPP Pratama Balige. Namun, sosialisasi yang telah dilakukan tersebut tidak selaras dengan jumlah UMKM yang memanfaatkan insentif PPh final ditanggung pemerintah.

Selanjutnya penelitian lainnya menyimpulkan bahwa segmen UMKM di Indonesia mengalami imbas dari pandemi COVID-19, antara lain turunnya penjualan, sulitnya pendanaan, 


\section{EDUCORETAX}

Volume 1 No. 2, Juni 2021

kendala penyaluran hasil produksi, dan langkanya bahan baku (Sugiri, 2020). Penelitian tersebut menunjukkan hal yang sama pada UMKM di Kabupaten Toba. Pemerintah Kabupaten Toba melalui Dinas Koperasi Perdagangan dan UKM mengajukan 9.887 UMKM untuk menerima bantuan produktif usaha mikro (Mediadelegasi, 2020). Fakta tersebut menunjukkan bahwa UMKM di Kabupaten Toba juga terdampak pandemi COVID-19 dan sepatutnya memanfaatkan insentif pajak. Namun, jumlah UMKM yang memanfaatkan insentif pajak di KPP Pratama Balige, tidak berbanding lurus dengan UMKM terdampak COVID-19 di Kabupaten Toba. Tujuan penelitian adalah menguraikan implementasi PMK No 86/PMK.03/2020 atas insentif pajak, efektivitas pemanfaatan PMK No 86/PMK.03/2020 atas insentif pajak UMKM, dan mengidentifikasi hambatan dalam implementasi PMK No 86/PMK.03/2020 atas insentif pajak bagi UMKM di KPP Pratama Balige.

\section{KAJIAN PUSTAKA \\ Pengertian Pajak}

Pajak merupakan pungutan dari masyarakat kepada negara bersumber dari undang-undang dengan tidak mendapatkan timbal balik secara langsung dan yang dimanfaatkan untuk membiayai pengeluaran umum (Mardiasmo, 2011).

\section{Wajib Pajak UMKM}

Selanjutnya, Bank Dunia (2008) mengkategorikan UMKM berdasarkan jumlah karyawan, pendapatan setahun, dan jumlah aset (Yazfinedi, 2018). Usaha Mikro memiliki kurang dari 10 pekerja, pendapatan tahunan tidak lebih dari \$100.000, dan total aset tidak lebih dari \$100.000. Usaha kecil memiliki kurang dari 30 pekerja, pendapatan tahunan tidak lebih dari $\$ 3.000 .000$, dan total aset kurang dari $\$ 3.000 .000$. Usaha menengah memiliki pekerja hingga 300 pekerja, dengan pendapatan tahunan $\$ 15.000 .000$ dan total aset tidak lebih dari $\$ 15.000 .000$.

\section{Kewajiban Perpajakan UMKM}

Reformasi perpajakan dikenal sejak saat berubahnya ketentuan perpajakan tahun 1983. Sistem pemungutan pajak di Indonesia berubah dari official assessment system menjadi self assessment system. Official assessment system memberikan otoritas kepada petugas pajak untuk menetapkan jumlah pajak yang terutang, sedangkan self assessment system mengatur bahwa Wajib Pajak menghitung, menyetor dan melaporkan sendiri besarnya pajak yang terutang (Wahyuni, 2011). Peran petugas pajak dalam self assessment system adalah mengawasi melalui serangkaian tindakan pengawasan dan penegakan hukum. Oleh karena itu, Wajib Pajak dituntut untuk melaksanakan kewajiban pajaknya tersebut.

\section{Insentif Pajak}

Insentif pajak dapat diartikan sebagai suatu kebijakan sistem perpajakan yang memberikan kemudahan bagi Wajib Pajak baik bersifat finansial maupun non finansial. Pengertian insentif pajak mencakup semua hal yang memberikan keuntungan bagi Wajib Pajak. Viherkenttä (1991, dikutip dalam Nurlita, 2012) menguraikan sebagai berikut : "There is no universally accepted definition of a 'tax incentives'. In this study, the concept denotes a tax reduction intended to encourage business operations including inward foreign investmet". Pernyataan tersebut menjelaskan bahwa secara umum, tujuan insentif pajak adalah untuk mendorong suatu usaha termasuk untuk mendorong masuknya investasi asing. Didukung pernyataan United Nations Conference on Trade and Development (UNCTAD) (2000, dikutip dalam Nurlita, 2012) mendefinisikan insentif sebagai berikut.

"FDI incentives may be defined as any measurable advantages accorded to specific enterprises or categories of enterprises by (or at the direction of) a Government, in order to encourage them to behave in a certain manner. They include measures specifically designed either to increase the rate of return of a particular FDI undertaking, or to reduce (or redistribute) its costs or risks". 


\section{EDUCORETAX}

Volume 1 No. 2, Juni 2021

Pernyataan tersebut menjelaskan bahwa insentif dapat diartikan sebagai manfaat yang dapat diukur, didasarkan pada arahan pemerintah untuk menstimulasi suatu perusahaan bersikap dengan cara tertentu. Berdasarkan pengertian - pengertian tersebut, ditarik kesimpulan bahwa insentif pajak merupakan kebijakan perpajakan untuk mempengaruhi perilaku investor dalam menentukan akivitas bisnisnya.

\section{Insentif PPh Final UMKM}

Pandemi COVID-19 telah mempengaruhi stabilitas ekonomi di negara terdampak seperti Indonesia. Segmen usaha yang sangat terimbas ialah sektor UMKM. UMKM menjadi sektor paling rentan terkena hantaman pandemi COVID-19. Selama pandemi COVID-19, banyak UMKM yang mengalami kelesuan usaha bahkan sampai gulung tikar (Hendayana et al., 2020). UMKM memiliki pengaruh besar pada stabilitas perekonomian di Indonesia. Berdasarkan Laporan Analisis Daya Saing UMKM di Indonesia (2014) oleh BAPPENAS, dinyatakan bahwa UMKM memiliki beberapa peran yang cukup besar antara lain, memperluas lapangan kerja, menyerap tenaga kerja, membentuk PDB dan memberikan jaring pengaman terutama bagi masyarakat berpenghasilan rendah. Oleh karena itu, sangat penting bagi pemerintah untuk tetap menjaga kelangsungan UMKM terlebih saat pandemi COVID-19. Langkah pemerintah adalah dengan memberikan insentif final PP 23 Tahun 2018.

\section{METODE}

\section{Metode Dokumentasi}

Metode dokumentasi merupakan cara mengumpulkan data dengan mencatat data-data yang sudah ada (Hardani et al., 2020). Penulis menggunakan metode dokumentasi dengan pengambilan data melalui dokumen-dokumen yang telah tersedia berupa data sekunder yang relevan dengan topik atau masalah yang menjadi objek karya tulis tugas akhir. Adapun dokumen-dokumen yang dapat menjadi sumber data adalah dokumen resmi seperti peraturan perundang-undangan, buku, artikel, jurnal dan lain sebagainya.

\section{Metode Wawancara}

Penulis mengumpulkan data primer dengan melakukan wawancara semi terstruktur. Lincoln dan Guba (1988) dalam Metode Penelitian Kuantitatif dan Kualitatif, menyatakan bahwa tujuan dilakukannya wawancara adalah untuk mengkonstruksi terkait orang, peristiwa, kegiatan, lembaga, emosi, kehendak, dan lain sebagainya (Hardani et al.,2019). Dengan kemajuan teknologi informasi, wawancara dapat dilakukan tanpa tatap muka, yakni melalui telekomunikasi (Rahardjo, 2011). Masa pandemi COVID-19 saat ini mengharuskan penerapan physical distancing. Oleh karena itu, penulis melakukan wawancara kepada Account Representative pada KPP Pratama Balige melalui media telekomunikasi.

\section{HASIL DAN PEMBAHASAN}

\section{Implementasi PMK No 86/PMK.03/2020 atas Insentif Pajak Bagi UMKM di KPP Pratama Balige}

Sebagai wujud kebijakan pemerintah dalam pemulihan ekonomi pada masa pandemi COVID-19, PMK No 86/PMK.03/2020 ditetapkan dan diberlakukan sejak tanggal 16 Juli 2020. Tujuan ditetapkannya kebijakan tersebut adalah untuk memberikan kemudahan pemanfaatan insentif yang lebih luas. Salah satu sektor yang dapat memanfaatkan insentif berdasarkan PMK No 86/PMK.03/2020 adalah sektor UMKM atau biasanya disebut dengan insentif PPh Final PP 23. PPh Final PP 23 adalah Pajak Penghasilan dari pendapatan usaha yang diperoleh Wajib Pajak yang memiliki peredaran bruto tertentu. Sebagai upaya untuk memasyarakatkan agar insentif PPh Final PP 23 dapat dikenal, dipahami dan dimanfaatkan oleh Wajib Pajak UMKM, petugas pajak di KPP Pratama Balige melakukan sosialisasi bagi Wajib Pajak UMKM yang terdaftar di KPP Pratama Balige. Berdasarkan hasil wawancara yang dilakukan dengan Account 


\section{EDUCORETAX}

Volume 1 No. 2, Juni 2021

Representative, kegiatan sosialisasi yang telah dilakukan di KPP Pratama Balige dalam rangka memberikan edukasi tentang insentif PPh Final bagi UMKM adalah berupa penyampaian oleh masing - masing Account Representative kepada Wajib Pajak UMKM melalui media komunikasi seperti telepon dan Whatsapp, penyebaran informasi melalui media sosial KPP Pratama Balige, dan penyampaian informasi melalui aplikasi ZOOM. Sosialisasi secara jarak jauh tersebut dilakukan untuk menghindari semakin luasnya penyebaran COVID-19. Pelaksanaan sosialisasi dengan jarak jauh memberikan tantangan tersendiri baik bagi petugas pajak maupun Wajib Pajak. Contohnya adalah gangguan dalam jaringan yang kerap terganggu dan menyebabkan tidak maksimalnya penyampaian informasi dan umpan balik dari Wajib Pajak. Meskipun demikian, kegiatan tersebut diharapkan dapat membantu Wajib Pajak untuk memahami peraturan tersebut sehingga tetap dapat menjalankan kewajiban perpajakannya.

Berdasarkan hasil wawancara dengan Account Representative, kegiatan sosialisai dan beberapa edukasi yang telah dilakukan untuk memperkenalkan PMK No 86/PMK.03/2020 kepada Wajib Pajak UMKM dianggap cukup untuk memberikan pemahaman. Namun, masih banyak Wajib Pajak yang belum memanfaatkan insentif tersebut. Atas hasil pengumulan data dari KPP Pratama Balige, Wajib Pajak UMKM yang memanfaatkan insentif tersebut sebanyak 180 Wajib Pajak dari total Wajib Pajak UMKM sebanyak 9.012. Sehingga Wajib Pajak yang memanfaatkan insentif tersebut hanya sekitar 1,99 \% dari total Wajib Pajak UMKM di KPP Pratama Balige. Bagi Wajib Pajak yang ingin memanfaatkan insentif tersebut wajib menyampaikan laporan realisasi secara online. Apabila Wajib Pajak UMKM tidak memanfaatkan insentif tersebut, maka wajib menjalankan kewajibannya sesuai dengan PP 23 Tahun 2018, yaitu atas penghasilan dari usaha yang diterima atau diperoleh Wajib Pajak UMKM dikenai Pajak Penghasilan yang bersifat final dalam jangka waktu tertentu. Tarif PPh yang dikenakan atas pajak penghasilan final tersebut ialah sebesar $0,5 \%$ dikali dengan dasar pengenaan pajak (DPP). DPP tersebut merupakan total omzet bulanan sebelum diskon penjualan (Bandiyono \& Utami, 2021). Tujuan pemerintah memberikan insentif pajak bagi UMKM adalah untuk tetap menjaga kelangsungan usaha Wajib Pajak UMKM di masa pandemi COVID-19. Pandemi COVID-19 telah menyebabkan berkurangnya pendapatan Wajib Pajak UMKM sehingga banyak Wajib Pajak yang mengeluhkan bahwa pembayaran pajak sebesar $0.5 \%$ dari jumlah peredaran bruto setiap bulan sangat membebani. Namun meskipun demikian, setelah pemerintah memberikan kemudahan bagi Wajib Pajak UMKM melalui PMK No 86/PMK.03/2020, masih banyak Wajib Pajak KPP Pratama Balige yang tetap memilih membayarkan PPh Final PP 23 dibandingkan untuk memanfaatkan insentif tersebut.

Pemahaman Wajib Pajak dan pelaksanaan insentif PPh Final bagi UMKM membutuhkan keseragaman sehingga memudahkan Wajib Pajak dalam memanfaatkan insentif tersebut. DJP telah menerbitkan SE-43/PJ/2020 sebagai petunjuk pelaksanaan PMK No 86/PMK.03/2020. Berdasarkan hasil wawancara dengan Account Representative, penerapan insentif PPh Final bagi UMKM di KPP Pratama Balige dilaksanakan sesuai dengan ketentuan yang berlaku. Insentif PPh Final bagi UMKM dimanfaatkan untuk masa pajak April 2020 sampai dengan masa Desember 2020. Wajib Pajak UMKM yang telah mengetahui diberlakukannya insentif PPh Final PP 23 dan ingin memanfaatkan insentif tersebut dapat menyampaikan laporan realisasi secara online melalui laman www.pajak.go.id. Wajib Pajak terlebih dahulu mengunduh format dan jenis file laporan realisasi PPh Final Ditanggung Pemerintah. Selanjutnya, Wajib Pajak mengisi dengan lengkap dan benar serta mengunggah format dan file yang telah diisi tersebut dalam jangka waktu paling lambat tanggal 20 pada bulan berikutnya setelah masa pajak berakhir. Bagi Wajib Pajak yang menyampaikan laporan realisasi namun belum memiliki Surat Keterangan dan telah memenuhi persyaratan sesuai PMK No 99/PMK.03/2018, yaitu permohonan oleh tandatangan Wajib Pajak sendiri atau dengan kuasa, telah menyampaikan Surat Pemberitahuan Tahunan Pajak Penghasilan Tahun Pajak terakhir, 


\section{EDUCORETAX}

Volume 1 No. 2, Juni 2021

dan memenuhi kriteria Wajib Pajak, dapat diterbitkan surat keterangan. Penyampaian laporan realisasi setiap masa pajak merupakan pemenuhan kewajiban penyampaikan SPT Masa PPh untuk setiap masa pajak, sehingga Wajib Pajak yang telah menyampaikan laporan realisasi dianggap telah memenuhi kewajiban penyampaian SPT Masa PPh. Apabila Wajib Pajak tidak memiliki peredaran usaha pada bulan tertentu, maka Wajib Pajak tidak wajib menyampaikan SPT masa PPh.

DJP menerbitkan SE-43/PJ/2020 sebagai petunjuk pelaksanaan PMK No 86/PMK.03/2020. Kebijakan tersebut diterbitkan untuk memberikan uraian serta tahapan - tahapan yang rinci dan jelas sehingga Wajib Pajak UMKM dapat memanfaatkan insentif tersebut dalam menjalankan kewajiban pajaknya. Berdasarkan SE-43/PJ/2020 sebagai petunjuk pelaksanaan PMK No 86/PMK.03/2020, insentif PPh Final bagi UMKM dapat dimanfaatkan untuk masa pajak April 2020 sampai dengan masa Desember 2020. Untuk memanfaatkan insentif tersebut, Wajib Pajak UMKM dapat menyampaikan laporan realisasi secara online melalui laman www.pajak.go.id dengan mengunduh format dan jenis file laporan realisasi PPh Final Ditanggung Pemerintah. Setelah mengunduh format dan jenis file laporan realisasi PPh Final Ditanggung Pemerintah, Wajib Pajak mengisi dengan lengkap dan benar serta mengunggah format dan file yang telah diisi tersebut dalam jangka waktu paling lambat tanggal 20 pada bulan berikutnya setelah masa pajak berakhir. Bagi Wajib Pajak yang menyampaikan laporan realisasi namun belum memiliki Surat Keterangan dan telah memenuhi persyaratan sesuai PMK No 99/PMK.03/2018, dapat diterbitkan surat keterangan. Wajib Pajak yang telah menyampaikan laporan realisasi, dianggap telah memenuhi kewajiban penyampaian SPT Masa PPh. Berdasarkan uraian tersebut diatas, implementasi PMK No 86/PMK.03/2020 di KPP Pratama Balige telah sesuai dengan petunjuk pelaksanaan PMK No 86/PMK.03/2020 yang diatur dalam SE-43/PJ/2020.

\section{Efektivitas Pemanfaatan PMK No 86/PMK.03/2020 atas Insentif Pajak Bagi UMKM di KPP Pratama Balige}

Mendaftarkan diri dengan sadar dan sukarela merupakan salah satu wujud kepatuhan Wajib Pajak. Berdasarkan data yang diperoleh, sejak tahun 2018 sampai tahun 2020, jumlah Wajib Pajak UMKM yang mendaftarkan diri di KPP Pratama Balige selalu mengalami peningkatan. Peningkatan jumlah Wajib Pajak UMKM sejak tahun 2018 sampai tahun 2020 di KPP Pratama Balige dapat dilihat dari grafik pada Gambar 1.

Gambar 1. Grafik Perkembangan Jumlah Wajib Pajak UMKM KPP Pratama Balige Tahun 2018-2020

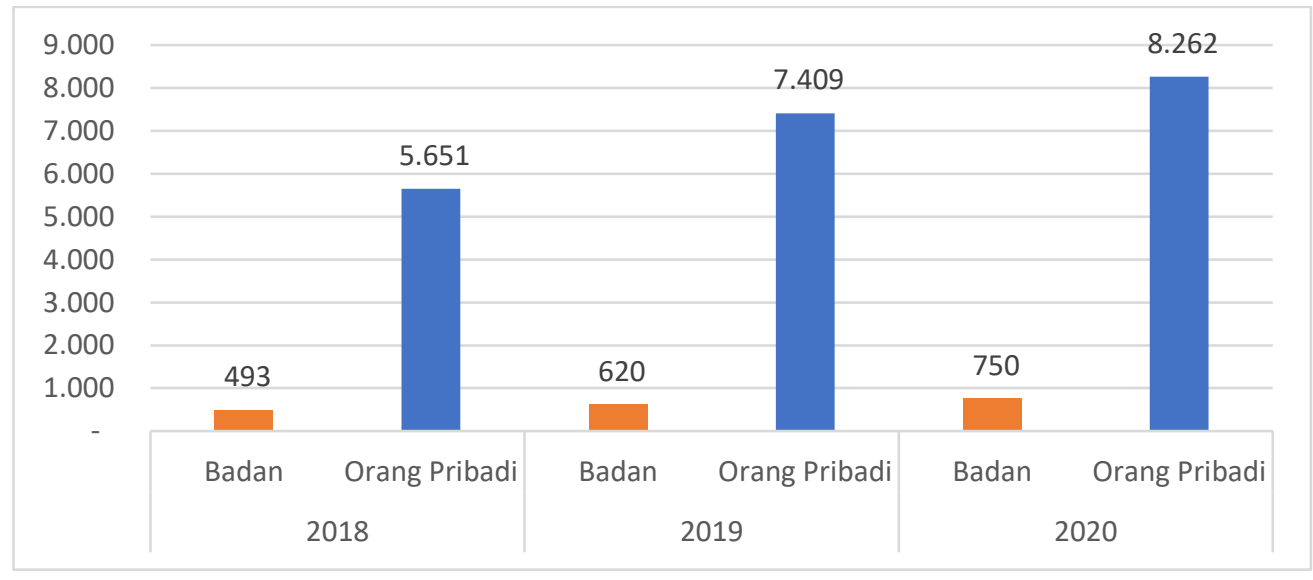

Sumber : Diolah dari Seksi Pengolahan Data dan Informasi KPP Pratama Balige 


\section{EDUCORETAX}

Volume 1 No. 2, Juni 2021

Grafik tersebut menunjukkan bahwa selama tiga tahun sejak tahun 2018 hingga tahun 2020, jumlah Wajib Pajak UMKM yang melakukan pendaftaran untuk mendapatkan NPWP selalu meningkat. Namun, peningkatan tersebut tidak diikuti dengan pertumbuhan yang optimal setiap tahunnya. Jumlah peningkatan Wajib Pajak UMKM tahun 2020 kurang dari jumlah peningkatan tahun 2019. Pada tahun 2019, peningkatan jumlah Wajib Pajak UMKM adalah sebanyak 1.885 atau setara dengan pertumbuhan sekitar $31 \%$ dari jumlah Wajib Pajak UMKM tahun 2018. Sedangkan pada tahun 2020 peningkatan jumlah Wajib Pajak UMKM adalah sebanyak 983 Wajib Pajak atau hanya sekitar 12\% dari jumlah Wajib Pajak UMKM tahun 2019. Meskipun setiap tahun jumlah Wajib Pajak UMKM mengalami peningkatan, namun apabila melihat pertumbuhannya, penurunan terjadi pada tahun 2020. Hal tersebut menurut Account Representative KPP Pratama Balige dipengaruhi oleh beberapa faktor. Peningkatan jumlah Wajib Pajak UMKM setiap tahunnya dipengaruhi oleh kepentingan pengurusan izin usaha dan syarat pencairan pinjaman. Hal tersebut kerap menjadi dasar Wajib Pajak UMKM untuk mendaftarkan diri. Sebaliknya penurunan pertumbuhan jumlah Wajib Pajak UMKM dipengaruhi oleh kondisi yang terjadi tahun 2020 yaitu pandemi COVID-19 yang menyebabkan kelesuan dalam kegiatan usaha.

PMK No 86/PMK.03/2020 khususnya bagi UMKM, diterbitkan dan diharapkan dapat dimanfaatkan dengan luas. Oleh karena itu, bagi Wajib Pajak UMKM yang belum memiliki NPWP diharapkan dengan kesadarannya dapat mendaftarkan diri untuk dapat menjalankan kewajibannya melalui pemanfaatan PMK No 86/PMK.03/2020 tersebut. Wajib Pajak yang telah memenuhi persyaratan subjektif dan objektif sesuai dengan ketentuan peraturan perundang-undangan perpajakan, wajib mendaftarkan diri pada kantor DJP yang wilayah kerjanya meliputi tempat tinggal atau tempat kedudukan Wajib Pajak, dan kepadanya diberikan NPWP. Persyaratan subjektif merupakan syarat yang sesuai dengan ketentuan mengenai subjek pajak dalam UU $\mathrm{PPh}$, seperti orang pribadi, badan, dan bentuk usaha tetap. Sedangkan persyaratan objektif merupakan syarat bagi subjek pajak yang menerima atau memperoleh penghasilan berupa setiap tambahan kemampuan ekonomis yang diterima atau diperoleh Wajib Pajak, baik yang berasal dari Indonesia maupun dari luar Indonesia, yang dapat dipakai untuk konsumsi atau untuk menambah kekayaan Wajib Pajak yang bersangkutan, dengan nama dan dalam bentuk apa pun. Sesuai dengan yang tercantum dalam Undang-Undang No 20 Tahun 2008 Tentang Usaha Mikro, Kecil dan Menengah, bahwa UMKM merupakan usaha produktif milik orang perorangan dan/atau badan usaha perorangan yang memenuhi kriteria usaha mikro, kecil dan menengah yang diatur dalam Undang-Undang. Pengertian tersebut menunjukkan bahwa UMKM telah memenuhi persyaratan sebagai subjek pajak. Sebagai suatu kegiatan usaha, UMKM juga menerima atau memperoleh penghasilan untuk kelangsungan usahanya. Dengan terpenuhinya syarat subjektif dan objektif tersebut, maka UMKM sebagai Wajib Pajak wajib melaksanakan ketentuan peraturan perundang-undangan yang berlaku dengan mendaftarkan diri ke kantor DJP yang wilayah kerjanya meliputi tempat kedudukan atau tempat tinggalnya. Namun, DJP yang bertindak sebagai pengawas dan penegak hukum di bidang perpajakan, memiliki kewenangan untuk memberikan NPWP secara jabatan kepada Wajib Pajak yang belum memiliki NPWP tetapi telah memenuhi syarat untuk memiliki NPWP.

Terbitnya PMK No 86/PMK.03/2020 atas insentif bagi UMKM adalah untuk memberikan kemudahan dalam pelaksanaan kewajiban pajak UMKM. Kemudahan tersebut berupa perlakuan pajak UMKM yang ditanggung oleh pemerintah agar Wajib Pajak tidak perlu lagi melakukan pembayaran pajak dalam jangka waktu tertentu. Upaya yang dilakukan Wajib Pajak untuk mendapatkan kemudahan tersebut adalah dengan menyampaikan laporan realisasinya setiap masa pajak. Lebih lanjut, diuraikan bahwa Wajib Pajak yang menyampaikan laporan realisasi dianggap telah memenuhi kewajiban membayar dan melaporkan kewajiban pajaknya. Hal tersebut merupakan salah satu manfaat yang dapat diperoleh oleh UMKM yang telah 


\section{EDUCORETAX}

Volume 1 No. 2, Juni 2021

memiliki NPWP atau telah mendaftarkan diri sebagai Wajib Pajak. Meskipun PMK No 86/PMK.03/2020 diterbitkan untuk memberikan kemudahan bagi Wajib Pajak UMKM, peraturan tersebut tidak menjadi faktor utama dalam meningkatkan kepatuhan Wajib Pajak UMKM untuk mendaftarkan diri. Sesuai dengan hasil wawancara dengan Account Representative KPP Pratama Balige yang menyatakan bahwa penerbitan PMK No 86/PMK.03/2020 tidak serta merta mempengaruhi peningkatan jumlah Wajib Pajak UMKM. Wajib Pajak di KPP Pratama Balige yang memanfaatkan PMK No 86/PMK.03/2020 atas insentif PPh Final PP 23 tersebut adalah Wajib Pajak UMKM yang telah mendaftarkan diri sebelum peraturan tersebut berlaku. Hal ini sesuai dengan pendapat yang menyatakan bahwa selain kewajiban, mendaftarkan diri untuk mendapatkan NPWP juga dilatarbelakangi oleh berbagai kebutuhan Wajib Pajak (Masruroh \& Zulaikha, 2013). Kebutuhan Wajib Pajak tersebut berkaitan dengan manfaat memiliki NPWP. Salah satu contoh manfaat memiliki NPWP sebagai kebutuhan Wajib Pajak adalah untuk memudahkan Wajib Pajak melakukan pinjaman dana pada lembaga keuangan (Bandiyono \& Sadry, 2018). Khususnya UMKM akan mendapatkan kemudahan akses kredit perbankan untuk mengembangkan usahanya. Wajib Pajak akan patuh untuk mendaftarkan diri apabila memperoleh manfaat atas kepemilikan NPWP (Putri, 2012). Meskipun demikian, kepemilikan NPWP tidak menjamin bahwa Wajib Pajak akan melaksanakan kewajiban perpajakannya.

Selain kepatuhan mendaftarkan diri, Wajib Pajak juga memiliki kewajiban yang mengacu pada sistem pemungutan pajak yang berlaku saat ini. Self assessment system menuntut agar Wajib Pajak memiliki kesadaran sendiri untuk menghitung, menyetorkan dan melaporkan sendiri pajak terutangnya dibawah pengawasan DJP. Melalui pemanfaatan PMK No 86/PMK.03/2020, UMKM dapat memenuhi kewajiban pajaknya dengan menyampaikan laporan realisasi secara online. Wajib Pajak UMKM yang telah menyampaikan laporan realisasi, dianggap telah memenuhi kewajiban penyetoran pajak dan penyampaian SPT Masa. Oleh karena itu, dengan memanfaatkan PMK No 86/PMK.03/2020, kewajiban menghitung, menyetorkan dan melaporkan sendiri pajak terutangnya telah dipenuhi.

Sesuai dengan PMK No 86/PMK.03/2020, Wajib Pajak UMKM yang mendapatkan insentif ditanggung oleh pemerintah adalah Wajib Pajak PP 23. Wajib Pajak PP 23 merupakan Wajib Pajak yang dikenakan PPh Final sebesar 0,5\% (nol koma lima persen) dari jumlah peredaran bruto. KPP Pratama Balige tidak menetapkan rincian target penerimaan pajak dari Wajib Pajak UMKM. Namun, meskipun demikian, KPP Pratama Balige tetap menetapkan target penerimaan dari Pajak Penghasilan yang meliputi Pajak Penghasilan Final. Perbandingan kontribusi penerimaan Pajak Penghasilan Final berdasarkan PP 23 Tahun 2018 dengan penerimaan pajak penghasilan secara keseluruhan di KPP Pratama Balige dapat dilihat dalam grafik pada Gambar 2.. Berdasarkan grafik tersebut, dapat dilihat bahwa realisasi penerimaan Pajak Penghasilan bersifat fluktuatif. Penerimaan PPh Final dan Pajak Penghasilan meningkat pada tahun 2019. Sedangkan penerimaan PPh Final dan Pajak Penghasilan pada tahun 2020 menurun. Namun berbeda halnya dengan penerimaan PPh Final UMKM. 


\section{EDUCORETAX}

Volume 1 No. 2, Juni 2021

\section{Gambar 2. Grafik Perbandingan Realisasi Penerimaan PPh di KPP Pratama Balige Tahun 2018-2020}

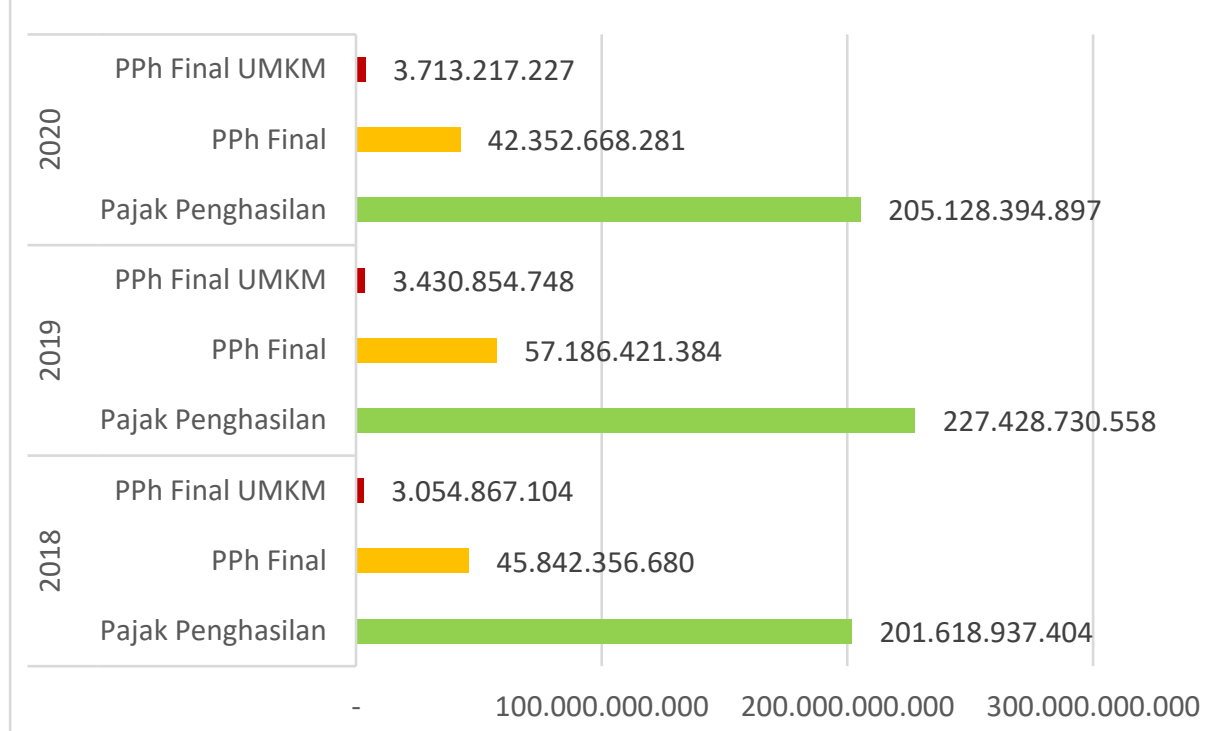

Sumber : Diolah dari Seksi Pengolahan Data dan Informasi KPP Pratama Balige

Penerimaan PPh Final UMKM selalu meningkat sejak tahun 2018 sampai 2020. Hal tersebut berbanding terbalik dengan kondisi ekonomi yang saat ini sedang tidak stabil oleh pandemi COVID-19. Selain itu, sesuai dengan jangka waktu yang diatur dalam PMK No 86/PMK.03/2020, bahwa insentif PPh Final UMKM dapat dimanfaatkan untuk masa pajak April sampai dengan masa pajak Desember tahun 2020. Bagi Wajib Pajak yang menyampaikan laporan realisasi, akan diberikan insentif berupa PPh final yang ditanggung pemerintah sehingga tidak melakukan penyetoran pajak seperti saat sebelum berlakunya PMK No 86/PMK.03/2020. PPh final yang ditanggung pemerintah tersebut dapat mempengaruhi penerimaan pada KPP Pratama Balige khususnya penerimaan PPh Final UMKM. Lebih lanjut, rincian penerimaan PPh Final UMKM tersebut untuk tiap masa pajak di KPP Pratama Balige digambarkan dalam grafik pada Gambar .

Gambar 3. Grafik Setoran PPh Final UMKM di KPP Pratama Balige Tahun 20182020

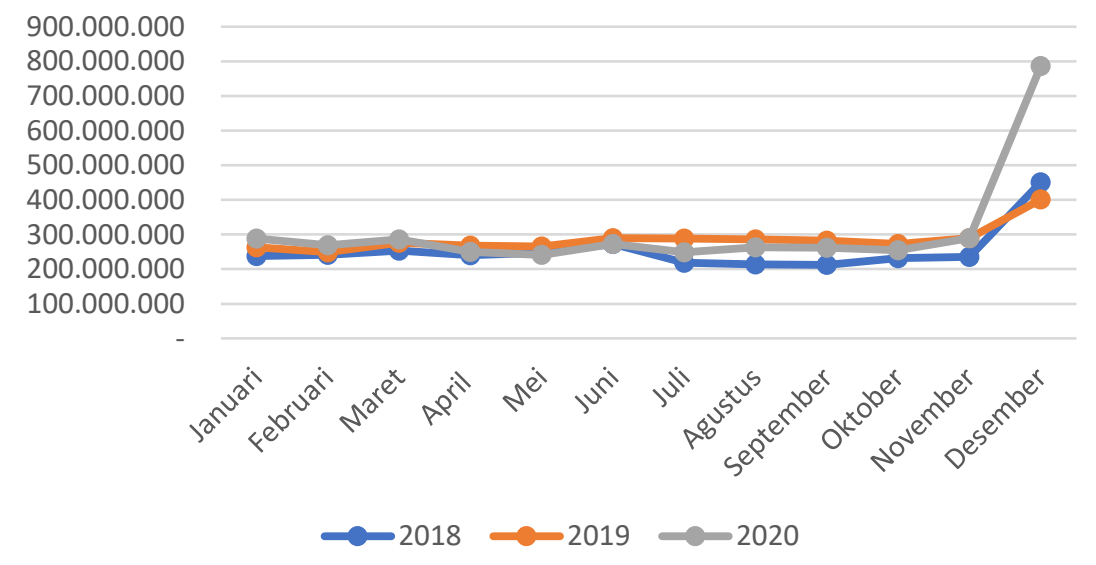

Sumber : Diolah dari Seksi Pengolahan Data dan Informasi KPP Pratama Balige Grafik tersebut menunjukkan bahwa setiap masa dalam satu tahun pajak, penerimaan PPh Final UMKM tidak berbeda secara signifikan kecuali pada masa Desember. Penerimaan PPh Final PP 23 masa Desember sejak tahun 2018 sampai dengan tahun 2020 selalu mengalami peningkatan yang signifikan dibandingkan masa Januari sampai November pada tahun pajak 


\section{EDUCORETAX}

Volume 1 No. 2, Juni 2021

yang sama. Berdasarkan hasil wawancara yang dilakukan dengan Account Representative, penerimaan PPh Final UMKM tetap meningkat disebabkan oleh banyaknya Wajib Pajak yang memilih untuk tetap membayarkan kewajibannya sesuai dengan PP 23 Tahun 2018.

Bastian (2010, dikutip dalam Jarnuzi et al., 2018) menyatakan efektivitas dapat ditunjukkan melalui kesuksesan atau kegagalan dalam pencapaian tujuan. Sehingga, dalam penelitian ini dikatakan efektivitas terjadi ketika PMK No 86/PMK.03/2020 atas Insentif Pajak Bagi UMKM mencapai tujuannya. Tujuan diterbitkannya kebijakan tersebut adalah untuk memberikan kemudahan bagi Wajib Pajak UMKM agar tetap dapat mempertahankan kelangsungan usahanya ditengah pandemi COVID-19. Kemudahan agar tetap dapat mempertahankan kelangsungan usahanya di tengah pandemi COVID-19, dapat diwujudkan dengan menjalankan kewajiban perpajakannya melalui pemanfaatan insentif, sehingga Wajib Pajak UMKM tidak lagi dibebani penyetoran pajak setiap masanya. Sebagaimana telah diuraikan sebelumnya, bahwa dengan mendaftarkan diri serta menyampaikan laporan realisasi, maka Wajib Pajak UMKM tidak perlu lagi menyetorkan PPh Final PP 23 nya. Namun, berdasarkan data yang diperoleh dan hasil wawancara dengan Account Representative sebagaimana telah diuraikan sebelumnya, menyatakan bahwa Wajib Pajak UMKM yang memanfaatkan insentif tersebut adalah Wajib Pajak UMKM yang telah terdaftar sebelum kebijakan tersebut berlaku. Selanjutnya, melihat dari sisi penerimaan PPh Final PP 23 di KPP Pratama Balige sebagaimana telah dijelaskan sebelumnya menunjukkan bahwa masih banyak Wajib Pajak UMKM yang tetap menyetorkan PPh Final PP 23 meskipun pemerintah sudah memberikan insentif untuk dimanfaatkan. Sehingga berdasarkan kriteria efektivitas yang telah dijelaskan, pemanfaatan PMK No 86/PMK.03/2020 atas Insentif Pajak Bagi UMKM di KPP Pratama Balige masih membutuhkan penyempurnaan, contohnya adalah perpanjangan jangka waktu. Sehingga dapat menunjukkan efektivitas demi tercapainya tujuan pemerintah untuk mempertahankan kelangsungan usaha Wajib Pajak UMKM pada masa pandemi COVID-19 melalui pemenuhan kewajiban perpajakannya yang serta merta dapat meningkatkan kepatuhan pajaknya.

\section{Hambatan dalam Implementasi PMK No 86/PMK.03/2020 atas Insentif Pajak Bagi UMKM di KPP Pratama Balige}

Berdasarkan hasil wawancara dengan Account Representative KPP Pratama Balige, pelaksanaan PMK No 86/PMK.03/2020 atas insentif PPh Final PP 23 tidak terlepas dari hambatan - hambatan yang menyebabkan pemanfaatan insentif PPh Final bagi UMKM tidak optimal. Hambatan atau kendala dalam melaksanakan suatu kebijakan khususnya suatu peraturan yang baru berlaku merupakan hal yang wajar dan kerap terjadi. Tidak hanya oleh Wajib Pajak, petugas pajak juga dapat menghadapai berbagai hambatan. Hal ini didukung oleh pernyataan bahwa hambatan yang bervariasi dapat dialami wajib pajak UMKM dan fiskus dikarenakan tidak semua wajib pajak UMKM paham serta patuh mengenai urusan administrasi kewajiban perpajakan mereka (Bandiyono \& Sadry, 2018). Oleh karena itu, diperlukan identifikasi hambatan yang dihadapi sehingga dapat melakukan mitigasi dan perbaikan untuk memperoleh solusi. Berikut merupakan hambatan yang ditemui oleh baik petugas pajak maupun Wajib Pajak dalam pelaksanaan pemanfaatan insentif PPh Final bagi UMKM.

1. Kurangnya Literasi Digital

Kemampuan memanfaatkan digital atau biasa disebut dengan literasi digital merupakan pemahaman dalam menggunakan perangkat digital atau jaringan untuk mendapatkan, menilai, dan menciptakan informasi serta menggunakannya secara bijak dan taat aturan dalam rangka membangun komunikasi dalam kehidupan sehari-hari (Kemendikbud, 2017). Indonesia adalah bangsa yang besar dan memiliki wilayah yang sangat luas berbentuk kepulauan. Beberapa daerah berbentuk pegunungan dan dataran sehingga lokasi pedesaan menyebar dan mengakibatkan pembangunan sarana komunikasi dan informasi cukup sulit dilakukan serta 


\section{EDUCORETAX}

Volume 1 No. 2, Juni 2021

perlu dukungan biaya yang tidak murah. Akibatnya infrastruktur teknologi informasi hanya terpusat di perkotaan. Pada akhirnya ketidakmerataan infrastuktur tersebut menimbulkan kesenjangan digital (Hidayat, 2014). Salah satunya adalah literasi digital di wilayah kerja KPP Pratama Balige khusunya bagi Wajib Pajak UMKM yang terdaftar di KPP Pratama Balige. Melalui PMK No 86/PMK.03/2020, DJP memberikan kemudahan bagi setiap UMKM yang ingin memanfaatkan insentif tersebut. Era digitalisasi dan pandemi COVID-19 yang saat ini sedang melanda merupakan faktor utama diberlakukannya kemudahan tersebut. Wajib Pajak tidak diwajibkan datang ke kantor pelayanan pajak karena dapat dilakukan hanya dengan mengakses internet. Namun, kemudahan tersebut tidak didukung dengan kemampuan memanfaatkan teknologi informasi oleh Wajib Pajak. Sesuai dengan petunjuk pelaksanaan pemanfaatan insentif PPh Final PP 23, bagi Wajib Pajak UMKM yang ingin memanfaatkan insentif tersebut wajib menyampaikan laporan realisasi secara online melalui laman www.pajak.go.id. Berdasarkan wawancara yang diperoleh dari Account Representative, di KPP Pratama Balige seorang Account Representative bertugas memberikan edukasi kepada Wajib Pajak UMKM yang ingin berkonsultasi terkait pemanfaatan insentif PPh Final PP 23. Menurut seorang Account Representative sebagai pegawai KPP Pratama Balige yang berhubungan langsung dengan Wajib Pajak UMKM yang ingin memanfaatkan insentif tersebut, tidak jarang Wajib Pajak tersebut mengeluhkan ketidakmampuan menggunakan tekonologi. Sehingga banyak Wajib Pajak UMKM yang memilih tetap membayar PPh Final PP 23 seperti sebelum berlakunya PMK No 86/PMK.03/2020. Selain itu, Wajib Pajak juga berpendapat bahwa dalam menyampaikan laporan realisasi, membutuhkan kemampuan menyusun laporan dalam file dengan format Microsoft Excel. Wajib Pajak UMKM mengungkapkan bahwa melakukan hal tersebut cukup menyita waktu dan membutuhkan perangkat teknologi yang tidak dimiliki oleh Wajib Pajak. Sehingga Wajib Pajak lebih memilih tidak melakukan penyampaian laporan realisasi untuk memperoleh insentif tersebut.

2. Sistem yang Terintegrasi

Account Representative mengemban tugas intensifikasi perpajakan melalui pemberian bimbingan atau himbauan, konsultasi, analisis dan pengawasan terhadap Wajib Pajak. Account Representative yang menjalankan fungsi pengawasan dan penggalian potensi Wajib Pajak, memiliki tugas melakukan pengawasan kepatuhan kewajiban perpajakan Wajib Pajak. Sama halnya dengan pelaksanaan insentif PPh Final PP 23 bagi UMKM, sesuai dengan petunjuk pelaksanaan pemanfaatan insentif PPh Final PP 23 bagi UMKM, dalam SE-43/PJ/2020 disampaikan bahwa salah satu tugas dan tanggung jawab Account Representative adalah dalam fungsi pengawasan. Petunjuk pelaksanaan tersebut mengatur tentang tata cara pengawasan atas pemanfaatan insentif PPh Final PP 23 bagi UMKM dengan melakukan pengawasan melalui sistem informasi DJP. Dalam hal Wajib Pajak UMKM belum menyampaikan laporan realisasi sesuai dengan tanggal yang telah ditentukan, sistem informasi DJP akan menyampaikan pemberitahuan kepada Account Representative untuk selanjutnya ditindaklanjuti. Menurut Account Representative KPP Pratama Balige, sistem pengawasan tersebut belum dapat dimanfaatkan sebagaimana dimaksud. Kebijakan yang baru berlaku tersebut membutuhkan penyempurnaan agar sistem yang terintegrasi dapat digunakan sebagai upaya meningkatkan pemanfaatan insentif PPh Final PP 23 bagi UMKM.

3. Kesadaran Wajib Pajak

Tujuan diterbitkannya PMK No 86/PMK.03/2020 khususnya insentif PPh Final PP 23 bagi UMKM adalah untuk memberikan kemudahan bagi Wajib Pajak UMKM agar tetap dapat mempertahankan kelangsungan usahanya di tengah pandemi COVID-19. Pemerintah berharap dengan memberikan insentif tersebut, Wajib Pajak UMKM sebagai penyokong perekonomian di Indonesia, dapat mempertahankan stabilitas ekonomi. Wajib Pajak yang memanfaatkan insentif tersebut, maka diberikan keringanan pembayaran pajak karena ditanggung oleh 


\section{EDUCORETAX}

Volume 1 No. 2, Juni 2021

pemerintah. Caranya adalah dengan menyampaikan laporan realisasi setiap masa pajak. Dengan demikian, penyampaian laporan realisasi merupakan pemenuhan kewajiban menyampaikan SPT Masa PPh untuk setiap masa pajak. Sehingga Wajib Pajak yang telah menyampaikan laporan realisasi dianggap telah memenuhi kewajiban penyampaian SPT Masa PPh. Namun, pemahaman tentang kewajiban perpajakan yang harus dilaksanakan oleh Wajib Pajak masih minim. Kesadaran yang rendah akan kepatuhan pajak menyebabkan tidak tercapainya tujuan yang diharapkan oleh pemerintah. Sebagaimana diketahui insentif PPh Final PP 23 bagi UMKM merupakan kebijakan yang baru dan membutuhkan bimbingan teknis. KPP Pratama Balige telah melakukan berbagai upaya untuk memperkenalkan dan mengedukasi Wajib Pajak UMKM melalui sosialisasi agar Wajib Pajak dapat memanfaatkan insentif PPh Final PP 23 tersebut. Namun, peranan penting dari Wajib Pajak juga merupakan faktor yang sangat penting. Apabila Wajib Pajak tidak memiliki kesadaran akan kewajiban perpajakannya, maka kebijakan tersebut akan sulit mencapai hasil yang optimal.

\section{PENUTUP}

\section{Simpulan}

Implementasi PMK No 86/PMK.03/2020 atas insentif pajak bagi UMKM di KPP Pratama Balige dilaksanakan dengan terlebih dahulu memberikan sosialisasi kepada Wajib Pajak UMKM agar insentif tersebut dapat dikenal, dipahami dan dimanfaatkan oleh Wajib Pajak UMKM. Kegiatan sosialisasi tersebut merupakan sosialisasi jarak jauh, yaitu dengan penyampaian oleh masing - masing Account Representative kepada Wajib Pajak UMKM melalui media komunikasi seperti telepon dan Whatsapp, penyebaran informasi melalui media sosial KPP Pratama Balige, dan penyampaian informasi melalui aplikasi ZOOM. Selanjutnya, setiap tahapan pelaksanaan untuk memanfaatkan PMK No 86/PMK.03/2020 atas insentif pajak bagi UMKM di KPP Pratama Balige, telah sesuai dengan petunjuk pelaksanaan yang ditetapkan oleh DJP yaitu SE-43/PJ/2020. Insentif pajak bagi UMKM dapat dimanfaatkan untuk masa pajak April 2020 sampai dengan masa Desember 2020. Wajib Pajak UMKM dapat menyampaikan laporan realisasi secara online melalui laman www.pajak.go.id dengan terlebih dahulu mengunduh format dan jenis file laporan realisasi PPh Final Ditanggung Pemerintah. Selanjutnya, Wajib Pajak mengisi dengan lengkap dan benar serta mengunggah format dan file yang telah diisi tersebut dalam jangka waktu paling lambat tanggal 20 pada bulan berikutnya setelah masa pajak berakhir. Laporan realisasi yang telah disampaikan oleh Wajib Pajak tersebut merupakan pemenuhan kewajiban penyampaikan SPT Masa PPh untuk setiap masa pajak, sehingga Wajib Pajak yang telah menyampaikan laporan realisasi dianggap telah memenuhi kewajiban penyampaian SPT Masa PPh. Berdasarkan kegiatan sosialisasi yang telah dilakukan dan memberikan petunjuk pelaksanaan yang telah diupayakan, data yang diperoleh menunjukkan bahwa Wajib Pajak yang memanfaatkan insentif tersebut hanya sekitar 1,99\% dari total Wajib Pajak UMKM di KPP Pratama Balige.

Pemanfaatan PMK No 86/PMK.03/2020 atas insentif pajak bagi UMKM di KPP Pratama Balige dapat dilihat melalui data jumlah Wajib Pajak UMKM yang menggunakan insentif tersebut. Sejak tahun 2018 sampai dengan tahun 2020, jumlah Wajib Pajak UMKM mengalami peningkatan. Namun pada tahun 2020 yaitu tahun berlakunya PMK No 86/PMK.03/2020, kenaikan jumlah Wajib Pajak UMKM di KPP Pratama Balige tidak mengalami pertumbuhan dari tahun sebelumnya. Pada tahun 2019 kenaikan jumlah Wajib Pajak UMKM mencapai 31\% dari tahun 2018, sedangkan tahun 2020 hanya mencapai 12\% dari tahun 2019. Selain itu, Account Representative KPP Pratama Balige menyatakan bahwa Wajib Pajak UMKM yang memanfaatkan insentif tersebut adalah Wajib Pajak UMKM yang telah terdaftar di KPP Pratama Balige sebelum diterbitkannya PMK No 86/PMK.03/2020. Sisi penerimaan PPh Final UMKM juga dapat dilihat untuk mengetahui pemanfaatan PMK No 86/PMK.03/2020 atas 


\section{EDUCORETAX}

Volume 1 No. 2, Juni 2021

insentif pajak bagi UMKM di KPP Pratama Balige. Bagi Wajib Pajak yang menyampaikan laporan realisasi, akan diberikan insentif $\mathrm{PPh}$ final yang ditanggung pemerintah sehingga tidak melakukan penyetoran pajak seperti saat sebelum berlakunya peraturan tersebut. $\mathrm{PPh}$ final yang ditanggung pemerintah tersebut dapat menunjukkan pengaruh terhadap penerimaan pada KPP Pratama Balige khususnya penerimaan PPh Final UMKM. Penerimaan PPh Final dan Pajak Penghasilan di KPP Pratama Balige, meningkat pada tahun 2019. Sedangkan penerimaan PPh Final dan Pajak Penghasilan pada tahun 2020 menurun. Berbeda halnya dengan penerimaan PPh Final UMKM. Penerimaan PPh Final UMKM selalu meningkat sejak tahun 2018 sampai tahun 2020. Hal ini menunjukkan bahwa berlakunya PMK No 86/PMK.03/2020 untuk memberikan insentif bagi UMKM, tidak serta merta menyebabkan berkurangnya penerimaan PPh Final UMKM meskipun diketahui bahwa dengan memanfaatkan insentif tersebut Wajib Pajak tidak perlu lagi melakukan penyetoran pajak. Mengetahui perkembangan jumlah Wajib Pajak UMKM dengan jumlah Wajib Pajak UMKM yang memanfaatkan insentif tersebut, serta melihat penerimaan PPh Final UMKM, dapat dikatakan bahwa pemanfaatan PMK No 86/PMK.03/2020 atas insentif pajak bagi UMKM di KPP Pratama Balige masih membutuhkan penyempurnaan, contohnya dengan memberikan perpanjangan jangka waktu. Sehingga dalam pelaksanaannya dapat menunjukkan efektivitas demi tercapainya tujuan pemerintah, yaitu untuk mempertahankan kelangsungan usaha Wajib Pajak UMKM pada masa pandemi COVID19, melalui pemenuhan kewajiban perpajakannya yang serta merta dapat meningkatkan kepatuhan pajaknya.

Dalam mengimplementasikan PMK No 86/PMK.03/2020 atas insentif pajak bagi UMKM di KPP Pratama Balige, masih terdapat beberapa hambatan yang dihadapi. Adapun hambatan tersebut antara lain, kurangnya literasi digital di wilayah kerja KPP Pratama Balige khususnya Wajib Pajak UMKM, belum tersedianya sistem yang terintegrasi untuk menjalankan fungsi pengawasan oleh Account Representative, dan masih minimnya kesadaran Wajib Pajak UMKM dalam melaksanakan kewajiban perpajakannya.

\section{Saran}

Mengingat berbagai keterbatasan pada penelitian ini, penulis merekomendasikan saran untuk penelitian selanjutnya. Penulis menyarankan untuk menggunakan narasumber yang lebih banyak sehingga penelitian lebih komprehensif. Selain itu penulis juga menyarankan untuk menggunakan data terbaru sesuai dengan perpanjangan jangka waktu Insentif PPh Final bagi UMKM.

\section{DAFTAR PUSTAKA}

Badan Perencanaan Pembangunan Nasional. (2014). Laporan Analisis Daya Saing UMKM Di Indonesia. Badan Perencanaan Pembangunan Nasional

Badan Pusat Statistik. (2020). Statistik Karakteristik Usaha 2020. Badan Pusat Statistik.

Bandiyono, A., \& Sadry, D. A. P. (2018). Penerapan Peraturan Pemerintah Nomor 46 Tahun 2013 Terhadap Usaha Mikro Kecil Dan Menengah (UMKM). Jurnal Aplikasi Bisnis, $8(2)$.

Bandiyono, A., \& Utami, N. S. R. (2021). Evaluasi atas Implementasi PP Nomor 23 Tahun 2018 dan Implikasinya Terhadap Penerimaan Pajak dan Kepatuhan Wajib Pajak UMKM di Banjarmasin. Journal of Applied Accounting and Taxation, 6(1).

Direktorat Jenderal Pajak. (2020). Keputusan Direktur Jenderal Pajak KEP- 75/PJ/2020 Tentang Penetapan Perubahan Tugas dan Fungsi Kantor Pelayanan Pajak Pratama. Jakarta: Sekretariat Negara. 


\section{EDUCORETAX}

Volume 1 No. 2, Juni 2021

Direktorat Jenderal Pajak. (2020). Surat Edaran Direktur Jenderal Pajak SE-43/PJ/2020 Tentang Petunjuk Pelaksanaan PMK No 86/PMK.03/2020 tentang Insentif Pajak untuk Wajib Pajak Terdampak Pandemi Corona Virus Disease 2019. Jakarta: Sekretariat Negara.

Gugus Tugas Percepatan Penanganan COVID-19. (2020). Protokol Percepatan Penanganan Pandemi Covid-19 (Corona Virus Disease 2019). Gugus Tugas Percepatan Penanganan COVID-19.

Hardani, Auliya, N. H., Andriani, H., Fardani, R. A., Ustiawaty, J., Utami, E. F., Sukmana, D. J., \& Istiqomah, R. R. (2020). Metode Penelitian Kualitatif \& Kuantitatif. Pustaka Ilmu.

Hendayana, Y., Riantani, S., \& Dyahrini, W. (2020). Pelatihan dan Pengetahuan Tentang Perpajakan Secara Online di Era Pandemi Covid 19. Prosiding Konferensi Nasional Pengabdian Kepada Masyarakat dan Corporate Social Responsibility (PKM-CSR), 3.

Hidayat, Y. D. (2014). Kesenjangan Digital di Indonesia (Studi Kasus di Kabupaten Wakatobi). Jurnal Pekommas, 17(2).

Iswanto, \& Surisman. (2020). Perlukah PERPU No.1 Tahun 2020 Tentang Kebijakan Keuangan Negara Dalam Penanganan Corona Virus Disease 2019. Jurnal Ilmu Hukum, 4(1).

Jarnuzi, A., Wijayanti, R., \& Fitrianan, A. (2018). Efektivitas Penerimaan Pajak UMKM Sebelum dan Sesudah Penerapan PP No 23 Th 2018. Prosiding Seminar Nasional Akuntansi, Manajemen, Dan Keuangan, 1(1).

Kemendikbud. (2017). Panduan Gerakan Literasi Nasional. Sekretariat TIM GLN Kemendikbud.

Kementerian Koperasi dan UKM. (2018). Perkembangan Data Usaha Mikro , Kecil , Menengah Dan Usaha Besar. Kementerian Koperasi dan UKM.

Kementerian Keuangan. (2020). Laporan Kinerja Instansi Pemerintah Kantor Pelayanan Pajak Pratama Balige Tahun 2020. Kementerian Keuangan.

Kementerian Keuangan. (2020). Peraturan Menteri Keuangan Nomor 86/PMK. 03/2020 Tentang Insentif Pajak Untuk Wajib Pajak Terdampak Pandemi Corona Virus Disease 2019. Jakarta: Sekretariat Negara.

Kementerian Keuangan. (2018). Peraturan Menteri Keuangan Nomor 99/PMK.03/2018 tentang Pelaksanaan Peraturan Pemerintah Nomor 23 Tahun 2018 tentang Pajak Penghasilan atas Penghasilan dari Usaha yang Diterima atau Diperoleh Wajib Pajak yang Memiliki Peredaran Bruto Tertentu. Jakarta: Sekretariat Negara.

Kementerian Keuangan. (2017). Peraturan Menteri Keuangan Nomor 210/PMK.01/2017 Tentang Organisasi dan Tata Kerja Instansi Vertikal Direktorat Jenderal Pajak. Jakarta: Sekretariat Negara.

Mardiasmo. (2011). Perpajakan Edisi Revisi 2011. C.V Andi Offset.

Marlinah, L. (2020). Memanfaatkan Insentif Pajak UMKM Dalam Upaya Mendorong Pemulihan Ekonomi Nasional. Jurnal IKRA-ITH Ekonomika, 4(2).

Masruroh, S., \& Zulaikha. (2013). Pengaruh Kemanfaatan NPWP, Pemahaman Wajib Pajak, Kualitas Pelayanan, Sanksi Perpajakan Terhadap Kepatuhan Wajib Pajak (Studi Empiris pada WP OP di Kabupaten Tegal). Diponegoro Journal of Accounting, 2(4).

Mediadelegasi. (4 September 2020). 9.887 Pelaku UMKM Toba Menunggu Bantuan Kemenkop UKM. https://www.mediadelegasi.id/9-887-pelaku-umkm-toba-menunggu-bantuankemenkop-ukm/.

Mudiarti, H., \& Mulyani, U. R. (2020). Pengaruh Sosialisasi Dan Pemahaman Peraturan Kemauan Menjalankan Kewajiban Perpajakan Pada Masa Covid-19 ( Pada Umkm Orang Pribadi Sektor Perdagangan di Kudus). Accounting Global Journal, 4(2). 


\section{EDUCORETAX}

Volume 1 No. 2, Juni 2021

Nurlita, L. A. (2012). Analisis Kebijakan Pemberian Insentif Pajak Penghasilan Pada PP. No. 52/2011 Dalam Rangka Mendorong Investasi Industri Komponen Otomotif Di Indonesia. Universitas Indonesia.

Permadhi, P. L. O., \& Sudirga, I. M. (2020). Problematika Penerapan Sistem Karantina Wilayah Dan PSBB Dalam Penanggulangan Covid-19. Jurnal Kertha Semaya, 8(9).

Putri, W. P., \& Pusposari, D. (2012). Faktor-Faktor Yang Mempengaruhi Kepatuhan Pemilik Usaha Mikro, Kecil Dan Menengah (UMKM) Dalam Memiliki Nomor Pokok Wajib Pajak (NPWP) (Survey Pada Wajib Pajak Pemilik UMKM Yang Terdaftar Di Kpp Pratama Batu). Jurnal Ilmiah Mahasiswa FEB, 1(2).

Rahardjo, M. (2011). Metode Pengumpulan Data Penelitian Kualitatif.

Republik Indonesia. (2008). Undang-Undang Republik Indonesia Nomor 20 Tahun 2008 Tentang Usaha Mikro, Kecil, dan Menengah. Jakarta: Sekretariat Negara.

Republik Indonesia. (2009). Undang-Undang Nomor 6 Tahun 1983 Tentang Ketentuan Umum dan Tata Cara Perpajakan Sebagaimana Telah Beberapa Kali Diubah Terakhir Dengan Undang-Undang Republik Indonesia Nomor 11 Tahun 2020. Jakarta: Sekretariat Negara.

Republik Indonesia. (2008). Undang-Undang Nomor 36 Tahun 2008 Tentang Perubahan Keempat Atas Undang-Undang Nomor 7 Tahun 1983 Tentang Pajak Penghasilan. Jakarta: Sekretariat Negara.

Republik Indonesia. (2018). Peraturan Pemerintah Republik Indonesia Nomor 23 Tahun 2018 tentang Pajak Penghasilan atas Penghasilan dari Usaha yang Diterima atau Diperoleh Wajib Pajak yang Memiliki Peredaran Bruto Tertentu. Jakarta: Sekretariat Negara.

Setyawati, I. (2009). Peran Usaha Mikro Kecil Menengah (UMKM) Dalam Perekonomian Nasional. Jurnal Ekonomi, 26(288).

Sugiri, D. (2020). Menyelamatkan Usaha Mikro, Kecil dan Menengah dari Dampak Pandemi Covid-19. Media Pengkajian Manajemen Dan Akuntansi, 19(1).

Thaha, A. F. (2020). Dampak COVID-19 Terhadap UMKM di Indonesia. Jurnal Brand, 2(1).

Wahyuni, M.A. (2011). Tax Evasion: Dampak dari Self Assessment System. Jurnal Ilmiah Akuntansi Dan Humanika, 1(1).

Wildan, M. (15 September 2020). Ayo Ajukan! Anggaran Insentif PPh Final UMKM DTP Baru Terserap 12,5\%. https://news.ddtc.co.id/ayo-ajukan-anggaran-insentif-pph-finalumkm-dtp-baru-terserap-125-23951?page_y=105.

Yazfinedi. (2018). Usaha Mikro, Kecil, dan Menengah di Indonesia: Permasalahan dan Solusinya. Jurnal Ilmiah Kesejahteraan Sosial, 14(25). 